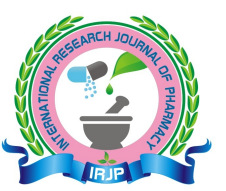

INTERNATIONAL RESEARCH JOURNAL OF PHARMACY

www.irjponline.com

ISSN $2230-8407$

\title{
Research Article \\ DEVELOPMENT AND VALIDATION OF ANALYTICAL METHOD FOR DETERMINATION OF ESOMEPRAZOLE SODIUM BY HPLC
}

Farhana Lipi *1, Md.Rabiul Islam ${ }^{1}$, Shahida Parvin ${ }^{2}$

${ }^{1}$ Pharmacy Discipline, Khulna University, Khulna-9208, Bangladesh

${ }^{2}$ Department of Pharmacy, Jahangirnagar University, Savar, Dhaka-1342, Bangladesh

*Corresponding Author Email: farhanalipiku04@gmail.com

Article Received on: 22/02/16 Revised on: 07/03/16 Approved for publication: 21/03/16

DOI: $10.7897 / 2230-8407.07543$

\section{ABSTRACTS}

A very simple, accurate, specific, precise and rapid reverse phase high performance liquid chromatography technique has been built up as well as validated to determine the Esomeprazole Sodium. The method is applicable for the quantitative analysis of the drug substance. Chromatographic separation was achieved on a Supelco $250-\mathrm{mm}, 4.6-\mathrm{mm}$, and $5-\mu \mathrm{m} \mathrm{C}-18$ analytical column with a mixture of Buffer and Acetonitrile at a volume ratio of $55: 45(\mathrm{v} / \mathrm{v})$ as mobile phase at a flow rate of $1.0 \mathrm{~mL} / \mathrm{min}$. The molecule eluted within a short runtime (within $7.0 \mathrm{~min}$ ). The eluted compound was monitored at a detector wavelength of $302 \mathrm{~nm}$ and the column oven temperature was maintained at $25^{\circ} \mathrm{C}$. The developed method was validated according to ICH guidelines. The high recovery and low relative standard deviation confirm the suitability of the method for determination of Esomeprazole Sodium. The repeatability and intermediate precision, expressed by the \% RSD, were less than $2 \%$. Accuracy (\% recovery: 98.00 $102.00 \%$ ) was found to satisfactory. The method was validated by determining its accuracy, precision, system suitability, linearity and robustness. Validation studies reveal that the method is simple, specific, rapid, reproducible, precise and accurate, which is useful for the routine determination of Esomeprazole Sodium.

Keywords: Method Development, Esomeprazole Sodium, HPLC, Validation.

\section{INTRODUCTION}

Esomeprazole Sodium ${ }^{1-5}$ is the form of S-isomer of Omeprazole as Sodium salt, which act as proton pump inhibitor. Esomeprazole is actually protonated and then converted into sulfenamide in the parietal Cells of the stomach. This active achiral can bind some disulfide covalent bonds with an enzyme called proton pump hydrogen potassium adenosine triphosphatase or $\mathrm{H}+/ \mathrm{K}+$ ATPase. Thus, it can inhibit the activity of the last step of the gastric acid production by inhibiting the entrance of the $\mathrm{H}+$ ions into the gastric lumen. $\mathrm{H}+/ \mathrm{K}+$ ATPase enzyme is the integral membrane protein of our gastric parietal cell. Chemical name of Esomeprazole Sodium is Sodium 5-methoxy-2-[(S) - (4-methoxy- 3, 5-dimethylpyridin-2yl) methylsulfinyl] benzimidazol-1-ide (C17H18N3O3SNa) (figure 1) and the molecular weight is $367.397 \mathrm{~g} / \mathrm{mol}$. It is white to pale yellow powder and freely soluble in ethanol (96\%) as well as very soluble in water.

\section{MATERIALS \& METHODS}

\section{Reagents and Chemicals}

Dipotassium Hydrogen phosphate, Potassium dihydrogen phosphate, HPLC-grade Acetonitrile and Esomeprazole Sodium (active pharmaceutical substance and working standard) were gifted by Beximco Pharmaceuticals Ltd. HPLC-grade water was used to prepare all solutions.

\section{Instruments}

The chromatography was performed on liquid Chromatograph, Shimadzu LC 2010 dual detector equipped with an automatic injector with an injection volume of $100 \mu \mathrm{L}$. The HPLC system was equipped with LC solution Software.

\section{METHOD DEVELOPMENT}

\section{Preparation of Buffer Solution}

$0.524 \mathrm{~g}$ of Dipotassium hydrogen phosphate and $2.669 \mathrm{~g}$ of Potassium dihydrogen phosphate were taken in a $1000 \mathrm{~mL}$ of volumetric flask. $600 \mathrm{~mL}$ of water was added to dissolve the salts and finally water was added upto to $1000 \mathrm{~mL}$ and mixed well.

\section{Preparation of Mobile Phase}

Mixed buffer solution with Acetonitrile at a ratio of 55:45. It was filtered through a nylon filter having a nominal pore size not greater than $0.45 \mu \mathrm{m}$. Finally the mixture was degassed in an ultrasonic bath.

\section{Preparation of Standard Solution}

About $50 \mathrm{mg}$ of Esomeprazole Sodium standard was taken in a $100 \mathrm{~mL}$ volumetric flask and $50 \mathrm{~mL}$ of the mobile phase was added to dissolve. Finally, mobile phase was added upto to 100 $\mathrm{mL} .5 \mathrm{~mL}$ of this solution was diluted to $50 \mathrm{~mL}$ with the mobile phase. It was filtered through a nylon filter having a nominal pore size not greater than $0.45 \mu \mathrm{m}$. 


\section{Preparation of Sample Solution}

About $50 \mathrm{mg}$ of the substance to be examined was taken in a $100 \mathrm{~mL}$ volumetric flask and $50 \mathrm{~mL}$ of the mobile phase was added to dissolve. Finally, mobile phase was added upto to 100 mL. $5 \mathrm{~mL}$ of this solution was diluted to $50 \mathrm{~mL}$ with the mobile phase. It was filtered through a nylon filter having a nominal pore size not greater than $0.45 \mu \mathrm{m}$.

\section{Preparation of Linearity Solution}

About $50 \mathrm{mg}$ of the substance to be examined was taken in a $100 \mathrm{~mL}$ volumetric flask and $50 \mathrm{~mL}$ of the mobile phase was added to dissolve. Finally, mobile phase was added upto to 100 mL. $5 \mathrm{~mL}$ of this solution was diluted to $50 \mathrm{~mL}$ with mobile phase. $1.0 \mathrm{~mL}, 1.6 \mathrm{~mL}, 2.0 \mathrm{~mL}, 2.4 \mathrm{~mL}, 3.0 \mathrm{~mL}$ of this was transferred into six different $10-\mathrm{mL}$ volumetric flasks to achieve $50 \%, 80 \%, 100 \%, 120 \%$ and $150 \%$ of the nominal concentration $(50 \mu \mathrm{g} / \mathrm{mL}$ for Esomeprazole Sodium) respectively. After that volume up to the mark with mobile phase and mixed well. These were filtered through a nylon filter having a nominal pore size not greater than $0.45 \mu \mathrm{m}$.

\section{Preparation of Blank Solution}

Mobile phase was used as blank.

\section{Chromatographic Conditions}

Supelco C18 $(250 \times 4.6 \mathrm{~mm} ; 5 \mu \mathrm{m})$ column was used for separation. The mobile phase consists of a mixture of Buffer and Acetonitrile at a volume ratio of 55:45 and filtered through a $0.45 \mathrm{~nm}$ nylon filter. The mobile phase delivered in isocratic mode at a flow rate of $1.0 \mathrm{ml} / \mathrm{min}$ quantified at $302 \mathrm{~nm}$.

\section{VALIDATION OF THE PROPOSED HPLC METHOD}

For validation of analytical method ${ }^{6-10}$, the guidelines of the International Conference on the Harmonization have suggested some essential validation characteristics. These validation characteristics are given below:

\section{System Suitability Test}

The HPLC system was equilibrated with the initial mobile phase composition trailed by 6 injections of the same standard. The system was considered suitable when relative standard deviation (\%RSD) is not more than $2.0 \%$, tailing factor is not more than 2.0 , and theoretical plate count is not less than 2000 .

\section{Specificity}

Specificity study was resolved by comparison of the chromatograms of blank solution, standard solution and sample solution.

\section{Linearity}

Linearity was determined from concentration $50-150 \%$ of the nominal concentration for a total of 7 seven different concentrations. The calibration curve was created by plotting the response factor (peak area) against the various concentrations of Esomeprazole Sodium.

\section{Range}

Linearity, accuracy and precision data were measured for establishing the range of this analytical system.

\section{Accuracy}

The accuracy of the method was formed by the recovery experiments and these experiments were carried out six times.

\section{Precision}

Repeatability (Method Precision)

Equilibrated the system and performed 6 consecutive injections of Sample Solution against a standard solution to determine relative standard deviation (RSD of 6 injections).

\section{Intermediate Precision}

A second analyst performed the same experiment as a repeatability experiment on different days and different equipment. For determination of intermediate precision, calculated the \%RSD of two analyst's results.

\section{Robustness}

The robustness was conducted by changing two different parameters (Flow rate and Temperature) of the method. Inject $20 \mu \mathrm{L}$ of the standard Solution maintaining chromatographic conditions. Change the chromatographic condition by changing the Flow rate, from $1.0 \mathrm{~mL} / \mathrm{min}$ to $1.2 \mathrm{~mL} / \mathrm{min}$ and to 0.8 $\mathrm{mL} / \mathrm{min}$. Again change the chromatographic condition by changing the Temperature of the column from $25^{\circ} \mathrm{C}$ to $30^{\circ} \mathrm{C}$ and later to $20^{\circ} \mathrm{C}$.

\section{RESULTS}

\section{System Suitability}

Chromatograms integrated automatically and then six system suitability injections were calculated. The relative standard deviation (\%RSD) of the peak areas and retention times were 0.146 (NMT 2.0\%) and 0.048 (NMT 2.0\%) respectively. The mean tailing factor was 1.01 (NMT 2.0) and the average theoretical plate was 6953 (NLT 2000) in Table 1.

\section{Specificity}

The specificity of the analyte peak was determined from that of the blank injection. The chromatograms of Blank injection, Standard injection and sample injection were justified to find the specificity of target analyte and found no peak at the same time in the blank chromatogram. Necessary chromatograms are presented from Figure 2 to 4.

\section{Linearity}

The actual concentrations of the seven standards against the respective peak areas were computed and the linear regression curve using Microsoft Office Excel ${ }^{\circledR}$ was generated. A linear relationship was determined through calculation of a regression line by the method of least squares (or similar technique). A plot of the data as well as the correlation coefficient, y-intercept and slope of the regression line were presented in Figure 5 and Table 2 .

\section{Range}

Linearity, accuracy and precision data were measured for establishing the range of this analytical system in Table 6.

\section{Accuracy}

The $\%$ of recovery and a standard deviation of $\%$ recovery were calculated as well as presented in (Table 3 ). The mean recovery and \%RSD were found to be $99.2 \%$ and $0.342 \%$ of Esomeprazole Sodium indicating very good reproducibility of the developed HPLC method of Esomeprazole Sodium.

\section{Precision}

\section{Repeatability (Method Precision)}

Concentration values were calculated from the corresponding peak areas for six concentrations and relative standard deviation (\%RSD) was found $0.103 \%$ in Table 4. 
Intermediate Precision

Analysis results which were carried out two different analysts found very similar results and their \%RSD of \% recovery were $0.103 \%$ and $0.261 \%$ respectively in Table 5 .

\section{Robustness}

There was no significant effect was observed for accuracy and repeatability because of the change of flow rate and temperature. The specificity of this method remains unaffected by these changes (Table 7). So the method is considered robust.<smiles></smiles>

Figure 1: structure of esomeprazole sodium

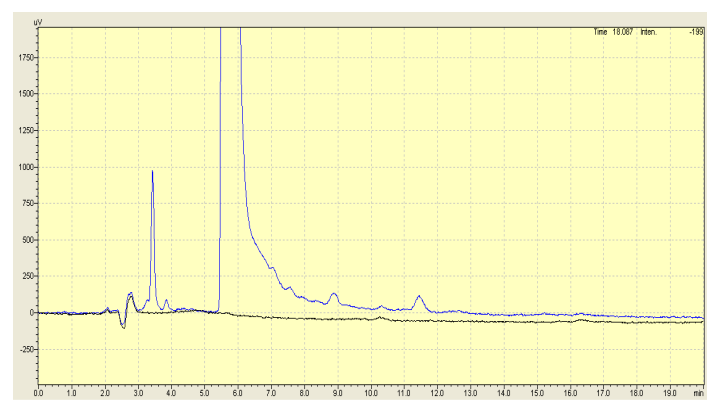

Figure 2: chromatogram comparison between blank and sample

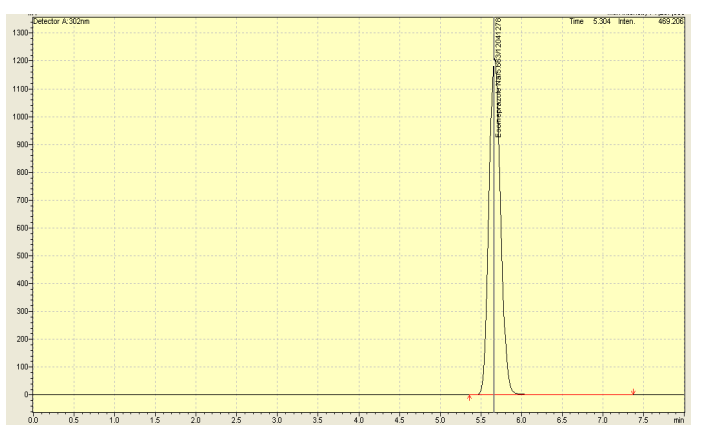

Figure 4: chromatogram of standard

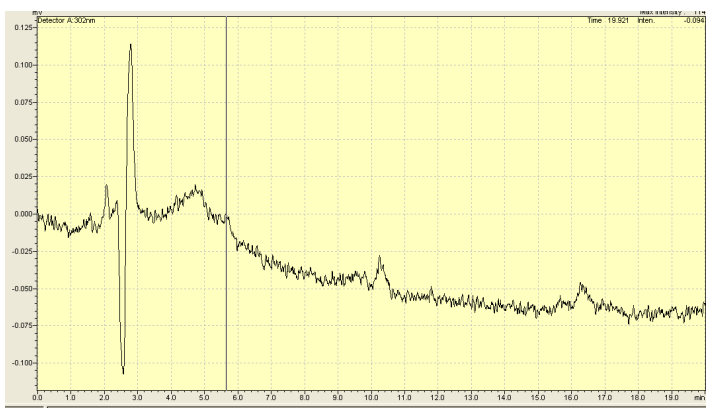

Figure 3: chromatogram of blank

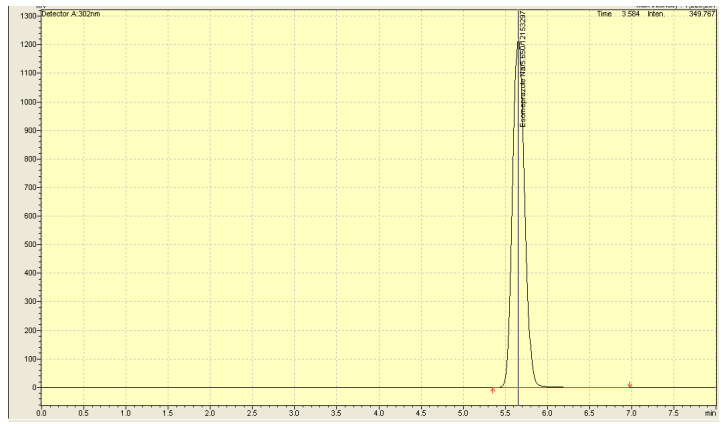

Figure 5: chromatogram of sample

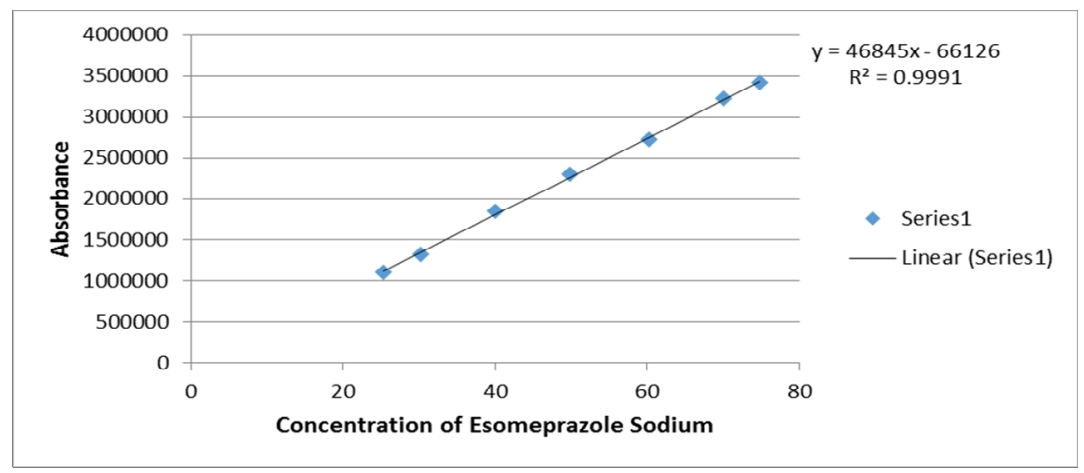

Figure 6: linearity curve 
Farhana Lipi et al. Int. Res. J. Pharm. 2016, 7 (5)

Table 1: System Suitability Study

\begin{tabular}{|c|c|c|c|c|}
\hline Injection & Peak area & Retention Time & Theoretical plate & Tailing Factor \\
\hline 1 & 2249890 & 5.938 & 6677 & 0.99 \\
\hline 2 & 2247643 & 5.945 & 6859 & 1.01 \\
\hline 3 & 2242139 & 5.944 & 7061 & 1.02 \\
\hline 4 & 2242534 & 5.942 & 7023 & 1.02 \\
\hline 5 & 2242743 & 5.944 & 7041 & 1.02 \\
\hline 6 & 2243032 & 5.946 & 7055 & 1.01 \\
\hline Average $(\mathrm{n}=6)$ & 2244664 & 5.943 & 6953 & 1.01 \\
\hline \%RSD & 0.146 & 0.048 & & N/A \\
\hline
\end{tabular}

Table 2: Linearity study

\begin{tabular}{|c|c|c|c|}
\hline No. & Nominal value $(\%)$ & Conc. of sample $(\mu \mathrm{g} / \mathrm{mL})$ & Peak areas \\
\hline 1 & 50 & 25.3 & 1106780 \\
\hline 2 & 60 & 30.2 & 1322940 \\
\hline 3 & 80 & 40.1 & 1849453 \\
\hline 4 & 100 & 49.9 & 2301441 \\
\hline 5 & 120 & 60.2 & 2729801 \\
\hline 6 & 140 & 70.1 & 3233082 \\
\hline 7 & 150 & 74.8 & 3417609 \\
\hline \multicolumn{2}{|c|}{ Correlation coefficient $\left(\mathrm{R}^{2}\right)$} & 0.9991 \\
\hline
\end{tabular}

Table 3: Accuracy Study

\begin{tabular}{|c|c|c|c|c|c|}
\hline Nominal Value (\%) & $\begin{array}{c}\text { Wt. of sample } \\
(\mathrm{mg})\end{array}$ & Peak area of Sample & $\begin{array}{c}\text { Wt. of standard } \\
(\mathrm{mg})\end{array}$ & $\begin{array}{c}\text { Peak area } \\
\text { of standard }\end{array}$ & $\begin{array}{c}\text { Recovery } \\
(\%)\end{array}$ \\
\hline \multirow{3}{*}{$80 \%$} & 40.1 & 1849453 & \multirow{2}{*}{49.8} & 2295842 & 99.1 \\
\cline { 2 - 3 } & 40.0 & 1831334 & & 98.4 \\
\cline { 2 - 3 } & 40.2 & 1855661 & & 99.2 \\
\hline \multirow{2}{*}{$100 \%$} & 50.0 & 2301441 & & 98.9 \\
\cline { 2 - 3 } & 49.9 & 2310143 & & 99.5 \\
\cline { 2 - 3 } & 50.0 & 2310112 & & 99.3 \\
\hline \multirow{2}{*}{$120 \%$} & 60.2 & 2779801 & & 99.3 \\
\cline { 2 - 3 } & 60.1 & 2779201 & & 99.4 \\
\cline { 2 - 3 } & 60.1 & 2779949 & & 99.4 \\
\hline \multicolumn{3}{|c|}{ Average (n=9) } & & 99.2 \\
\hline
\end{tabular}

Table 4: Repeatability (Method Precision) Study

\begin{tabular}{|c|c|c|c|c|c|}
\hline No. & $\begin{array}{c}\text { Wt. of sample } \\
(\mathrm{mg})\end{array}$ & $\begin{array}{c}\text { Peak area of } \\
\text { sample }\end{array}$ & $\begin{array}{c}\text { Wt. of standard } \\
(\mathrm{mg})\end{array}$ & $\begin{array}{c}\text { Peak area of } \\
\text { standard }\end{array}$ & $\begin{array}{c}\text { Recovery } \\
(\%)\end{array}$ \\
\hline 1 & 50.1 & 2308610 & 50.4 & 2325451 & 99.0 \\
\hline 2 & 50.1 & 2313501 & & & 99.2 \\
\hline 3 & 49.4 & 2279684 & & & 99.1 \\
\hline 4 & 49.2 & 2273009 & & 99.2 \\
\hline 5 & 50.3 & 2325685 & & 99.3 \\
\hline 6 & 49.9 & 2304594 & & 99.2 \\
\hline \multicolumn{2}{|c|}{ Average (n=6) } & & 99.2 \\
\hline \multicolumn{7}{|c|}{$\%$ Relative standard deviation } \\
\hline
\end{tabular}

Table 5: Intermediate precision Study

\begin{tabular}{|c|c|c|c|c|c|c|}
\hline Analyst & No. & $\begin{array}{l}\text { Wt. of sample } \\
(\mathrm{mg})\end{array}$ & $\begin{array}{c}\text { Peak areas of } \\
\text { Sample }\end{array}$ & $\begin{array}{c}\text { Wt. of standard } \\
(\mathrm{mg})\end{array}$ & $\begin{array}{c}\text { Peak area } \\
\text { of standard }\end{array}$ & Assay \\
\hline \multirow[t]{6}{*}{ Analyst 1} & 1 & 50.1 & 2308610 & \multirow[t]{6}{*}{50.4} & \multirow[b]{6}{*}{2325451} & 99.0 \\
\hline & 2 & 50.1 & 2313501 & & & 99.2 \\
\hline & 3 & 49.4 & 2279684 & & & 99.1 \\
\hline & 4 & 49.2 & 2273009 & & & 99.2 \\
\hline & 5 & 50.3 & 2325685 & & & 99.3 \\
\hline & 6 & 49.9 & 2304594 & & & 99.2 \\
\hline \multicolumn{6}{|c|}{ Average $(n=6)$} & 99.2 \\
\hline
\end{tabular}


Farhana Lipi et al. Int. Res. J. Pharm. 2016, 7 (5)

\begin{tabular}{|c|c|c|c|c|c|c|}
\hline \multicolumn{6}{|c|}{$\%$ Relative standard deviation } & 0.103 \\
\hline \multirow[t]{6}{*}{ Analyst 2} & 1 & 51.1 & 2358298 & \multirow[t]{6}{*}{49.4} & \multirow[b]{6}{*}{2279840} & 99.1 \\
\hline & 2 & 50.3 & 2330530 & & & 99.5 \\
\hline & 3 & 50.6 & 2345958 & & & 99.6 \\
\hline & 4 & 50.7 & 2337827 & & & 99.0 \\
\hline & 5 & 50.9 & 2349510 & & & 99.1 \\
\hline & 6 & 50.9 & 2358299 & & & 99.5 \\
\hline \multicolumn{6}{|c|}{ Average $(n=6)$} & 99.3 \\
\hline \multicolumn{6}{|c|}{$\%$ Relative standard deviation } & 0.261 \\
\hline
\end{tabular}

Table 6: Range Study

\begin{tabular}{|c|c|c|c|}
\hline Parameter & Concentration Range & Acceptance Limit & Result \\
\hline Linearity & $50 \%$ to $150 \%$ & $\mathrm{R}^{2}>0.995$ & 0.9991. \\
\hline Accuracy & $80 \%$ to $120 \%$ & $\begin{array}{c}\% \text { Recovery: } 98.0 \% \text { to } 102.0 \% \text { and } \% \\
\text { RSD NMT } 2.0 \% \text {. }\end{array}$ & $99.2 \%$ and $0.342 \%$. \\
\hline Repeatability & $100 \%$ & $\%$ RSD of $\%$ Recovery NMT $2.0 \%$. & $0.103 \%$. \\
\hline $\begin{array}{l}\text { Intermediate } \\
\text { precision }\end{array}$ & $100 \%$ & $\%$ RSD of two analysts NMT $2.0 \%$. & $\begin{array}{c}\% \text { RSD of } 1^{\text {st }} \text { analyst and } 2^{\text {nd }} \text { analyst were } \\
0.103 \% \text { and } 0.261 \% \text { respectively. }\end{array}$ \\
\hline
\end{tabular}

Table 7: System Suitability Study (Robustness Study)

\begin{tabular}{|c|c|c|c|}
\hline Parameter & \% RSD of Area & Theoretical Plate number & Tailing factor \\
\hline Flow rate +0.2 & 0.445 & 6943 & 1.01 \\
\hline Flow rate -0.2 & 0.348 & 7053 & 0.99 \\
\hline Column temperature at $30^{\circ} \mathrm{C}$ & 0.124 & 6983 & 1.04 \\
\hline Column temperature at $20^{\circ} \mathrm{C}$ & 0.139 & 7004 & 0.98 \\
\hline
\end{tabular}

\section{DISCUSSION}

From the above test parameters, it is proved that the System Suitability, Linearity Range, Accuracy, Precision (Repeatability, Intermediate), Specificity were found okay and within the required range. Therefore, this method is validated and suitable for the assay of Esomeprazole Sodium.

\section{ACKNOWLEDGEMENTS}

The authors are grateful to Beximco Pharmaceuticals Ltd, for providing the pure Esomeprazole Sodium sample and all necessary facilities and support for the completion of the tasks.

\section{REFERENCES}

1. Reynolds JC. Prokinetic agents: a key in the future of gastroenterology. Gastroenterol Clin North Am. 1989 Jun [cited 2015 Oct 29]; 18 (2): 437-57.

2. Scott LJ, Dunn CJ, Mallarkey G, Sharpe M. Esomeprazolea review of its use in the management of acid-related disorders. Drugs. 2002 [cited 2015 Dec 29]; 62:1503-38.

3. Andersson T, Hassan-Alin M, Hasselgren G, Rohss $\mathrm{K}$, Weidolf L. Pharmacokinetic studies with esomeprazole, the (S) -isomer of omeprazole. Clin Pharmacol. 2001 [cited 2015 Dec 29]; 40:411-26.

4. Sjostrand SE, Olbe L, Fellenius E. Milestones. In: Parnham MJ, Bruinvels J, editors. Milestones in Drug Therapy: proton pump inhibitors. Switzerland: Birkhauser Verlag; 1999.
5. Golan DE, Tashjian AH, Armstrong EJ, Armstrong AW. Principles of Pharmacology: The Pathophysiologic Basis of Drug Therapy. 2nd Edition. Philadelphia, Penn: Wolters Kluwer/Lippincott Williams \& Wilkins; 2008. p. 795

6. International Conference on Harmonization (ICH), Q2A: Text on Validation of Analytical Procedures: Definitions and Terminology, Federal Register, 1997.

7. International Conference on Harmonization (ICH), Q2B: Validation of Analytical Procedures: Methodology, Vol. 62, US FDA Federal Register, 1997

8. L.R. Snyder, J.J. Kirkland, and J.L. Glajch (Eds). Practical HPLC Method Development. Wiley-Interscience, New York, 1988, p. 402-438

9. S. Ahuja and S. Scypinski (Eds) Handbook of Modern Pharmaceutical Analysis. Academic Press, New York, 2001, p. $415-443$

10. Subhash Chandra Bose, Kotte, P.K Dubey and P.M. Murali. Core components of analytical method validation for small molecules: an overview. Int. Res. J. Pharm., 2012;3 (5): 111

\section{Cite this article as:}

Farhana Lipi, Md.Rabiul Islam, Shahida Parvin. Development and validation of analytical method for determination of Esomeprazole sodium by HPLC. Int. Res. J. Pharm. 2016;7(5):10-14 http://dx.doi.org/10.7897/2230-8407.07543

Source of support: Nil, Conflict of interest: None Declared

Disclaimer: IRJP is solely owned by Moksha Publishing House - A non-profit publishing house, dedicated to publish quality research, while every effort has been taken to verify the accuracy of the content published in our Journal. IRJP cannot accept any responsibility or liability for the site content and articles published. The views expressed in articles by our contributing authors are not necessarily those of IRJP editor or editorial board members. 